\title{
A Rose between Two Thorns; Tringham, Chatfield and Toxward, 1865 to 1870
}

\author{
Adrian Humphris, Wellington City Archives \& Geoff Mews, Independent Scholar
}

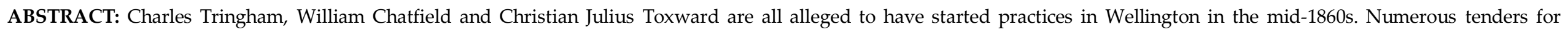

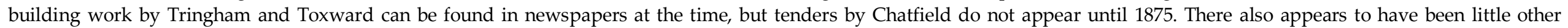
competition at the time.

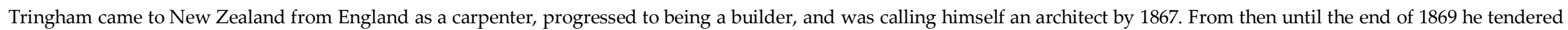

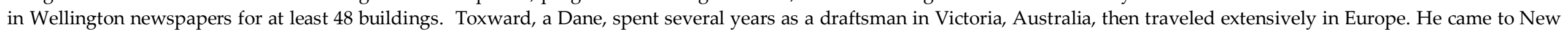

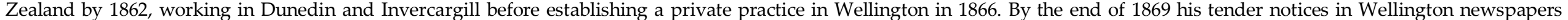

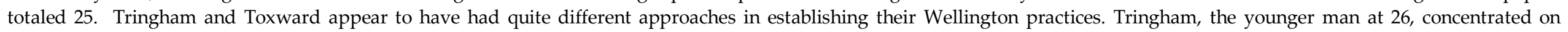

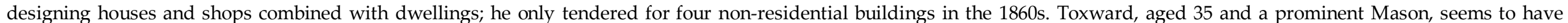

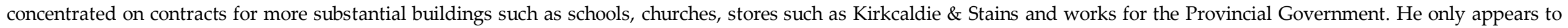
have designed three houses during this period.

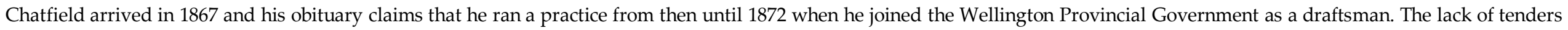

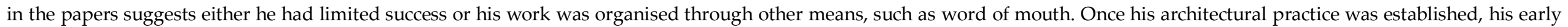
career (40 buildings in four years) closely paralleled that of Tringham.

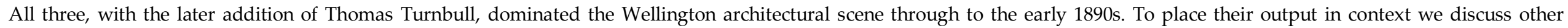
architects who appear in Wellington in the late 1860s, and the building profession during this time.

\section{Introduction}

Prior to the 1860s, Wellington was similar to most cities in New Zealand in that architectural practice was almost non-existent, with only a small handful of practitioners. Just a few names come readily to mind, and indeed very few true architects were on the scene. Robert Stokes appears to have been the first, but was actually employed as a survey assistant and did not make architecture his career. Several other surveyors and draftsmen turned their hands to designing colonial buildings, as did some builders and engineers. However, this situation began to change from the 1860s and by the middle of that decade there was growing evidence of architectural practice in the by-then capital city.

One of the difficulties in documenting architects and their work during this period is the particularly fragmentary nature of primary records. For most of our research we have had to rely largely on newspapers as a source for evidence of activity. By the 1860s Wellington had three papers in circulation. The New Zealand Spectator and Cook's Strait Guardian, printed first in 1844, persisted until 1865, from which time the daily Evening Post came into being. There was also the Wellington Independent which first appeared in 1860 . The opening ceremonies for the few new public buildings often got a mention, but the designer's name was not always recorded, nor 
was there necessarily a tender notice before construction commenced. In fact, it appears that it was not until late-1865, and the introduction of the Evening Post, that tenders by architects began appearing on a regular basis.

Low population numbers, the scarcity of architects, and the likely transfer of information by word of mouth all probably contributed to this situation. Very low numbers of buildings and hardly any building plans survive from this period. Even the designers that we do know about mostly did not have long-term architectural careers, or did not remain long in Wellington. This lack of local architects was commented on in the Wellington Independent in September 1862, noting that Barnard and Allen (who had designed the new St Matthew's Church in Auckland) had moved south;

the gentlemen alluded to as the architects are now settled in Wellington, having accepted engagements on the Provincial survey staff. There is abundant need of professional architects in this city, so that we trust we do public service by introducing them to notice. ${ }^{1}$

Unfortunately for Wellington, both were soon back in Auckland advertising as architects

\footnotetext{
1 "Local Intelligence: Architecture" p 2.
}

and surveyors; no local tenders by them have been found here.

Architects began to find their feet from the mid-1860s. The movement of the capital from Auckland to Wellington in 1865, with the subsequent growth of central government and business head offices, all contributed to the need for more substantial buildings. Many architects, both experienced and aspiring, migrated to Wellington to meet the need. There was growth in building, not only in the central business district, but also in providing houses for increasing numbers of civil servants, shopkeepers, bank employees and general labourers. In fact, the population of Wellington, which by 1861 was only just over 4,000 , had nearly doubled by 1870 . Similarly, the census for 1861 recorded 1,125 houses in Wellington City; by 1871 the census gave the number at $1,567 .^{2}$

For a while the lack of skilled architects was still felt; in 1866 the Otago inspector of the Bank of Australasia, about to erect a new branch in Wellington, reported "finding no practising architect of any standing, [I] should be obliged to get [the plans] drawn out in

${ }^{2}$ Results of Census of New Zealand 1861, 1871.
Otago."3 In fact it turned out even worse than that; the bank was finally designed by a $\mathrm{Mr}$ Moore, architect of Melbourne, and the materials for it shipped over to be assembled by a Melbourne contractor. ${ }^{4}$ The Wellington newspapers reported the facts but made no other comments. It was left to the Otago Daily Times reporter to remark: "It is rather a cut to our dignity to have houses built for us in another colony, and it is extremely likely to create a prejudice against the new bank." 5

\section{Leading Lights}

It is from the mid-1860s that the architects who are the main subjects of this paper first appear in Wellington; Charles Tringham, Christian Julius Toxward, and, supposedly, William Charles Chatfield. These three (with the later addition of Thomas Turnbull), dominated the Wellington architectural scene through to the early 1890s, although Chatfield too was something of a late starter. All three appear to have had quite different

3 "We find the following, in the Wellington letter ... [untitled column 4]" p 3.

4 "Local and General News: The Bank of Australasia" (19 May 1866):4 and "Local and General News: Bank of Australasia" (23 August 1866):4.

5 "We find the following, in the Wellington letter ... [untitled column 4]" p 3. 
backgrounds, and different approaches to establishing their practices. These can be seen quite clearly when looking back over their lives and careers.

Charles Tringham was born at Winforton in Hertfordshire, England, in 1841. He was the fourth of seven sons of schoolmaster William Tringham, and his wife Mary Ann. Little is known of his early education, but he apparently acquired woodworking skills. Tringham arrived in New Zealand at Auckland in December 1864 shown on the passenger list as a carpenter. He soon moved to Wellington and formed a partnership with a local builder, William Lawes. This lasted until the end of December 1866 when Charles branched out on his own as a builder and undertaker. Within a year, he was advertising himself as an architect and gaining a considerable number of contracts for houses, churches, hotels and a wide variety of other commercial premises. Almost two-thirds of his 1860s commissions were for houses; tenders for large groups (6-10 houses in a single tender) suggest speculative developments, possibly workers' dwellings.

His rise in Wellington society was undoubtedly helped by his marriage to
Margaret Hunter Bennett in April 1868. She was the daughter of Dr John Bennett, the first New Zealand Registrar-General. Lucrative contracts followed, including the Italianate house "Westoe" near Marton for Sir William Fox, and the extensions to William Clayton's former home in Hobson Street, now the nucleus of Queen Margaret College. He was also active in the Manawatu, as well as the Whanganui, Rangitikei and Wairarapa regions. In addition, there were contracts in southern Hawkes Bay as his career extended beyond the 1860s, including the original part of the Orouawharo mansion near Takapau in 1879.

Little is known of Tringham's other interests, except that he was a shareholder in at least three local Wellington gold mining ventures, acted as director for several companies and also owned land in central Petone which was specifically mentioned in his will. He was nearing the end of his architectural career in the early 1890s and in fact retired to the Wairarapa to farm before the turn of the century. He remained there until his death in 1916. Almost his last role in Wellington was as President of the Wellington Association of Architects in 1895 which capped off an exceptional career as one of the top three early major architects of the city. Over 340 designs by him have been recorded from tender notices and other data spanning a period from 1867 to 1890.

Christian Julius Toxward by comparison came from a rather different background. He was an extremely versatile character, being involved not only with architecture, but as a Justice of the Peace, company director, inventor, Danish consul, prominent Freemason and devoted family man during his time in Wellington. Born in Copenhagen, Denmark, in November 1831, Toxward was the son of Christian Henrich and Ane Margrethe; his father was a chair-maker by trade. He attended the Kunstakademiet (Fine Arts Academy) from 1841 to 1851, although it appears that he left without achieving a formal qualification. What happened next is variously interpreted. Obituaries say that he spent time working on the Australian goldfields, mainly around Ballarat, Victoria, before moving on to New Zealand. However, his Royal Institute of British Architects Directory entry states he spent about three years in Victoria as a draftsman and travelled extensively in Europe before setting up in practice as an architect in Wellington in 1865. Both statements could be more or less correct, 
but the timing of events remains unclear at present. An article in the Evening Post in January 1867 stated that Toxward then had 15 years' experience as an architect which would indicate he started in $1852 .{ }^{6}$ However, that leaves unanswered the question of his interlude on the goldfields.

Despite extensive searches we have not been able to document Toxward's actual arrival date in New Zealand; it appears to have been around $1861 .{ }^{7}$ In 1862 he was working in the Dunedin City Council Surveyor's Office with Augustus Poeppel, the City Surveyor and Engineer (they also advertised privately as architects). By 1864 he was working for the Southland Provincial Government apparently as a Clerk of Works and he got married in Invercargill in October 1864, to Jane Hall Hughes at St John's Church. According to the Intentions to Marry register he had been living in the town since early January 1864, giving his occupation as architect.

In November 1865, Toxward applied (from a

6 "District Court: This Day" p 2.

${ }^{7}$ A notice, indicative only, from the Southland Times at the time of his death in 1891, suggests that he arrived in New Zealand "thirty years ago," that is in 1861. "Death of an Early Southlander" p 2.
Wellington address) to the Wellington Provincial Government for a post in their Engineering Department, but he was told there was no vacancy. ${ }^{8}$ He began advertising his services in Wellington newspapers as an architect and civil engineer in April of the following year. His first actual commission appears to have been the design of the "Scotch Church," reported in the Wellington Independent in March 1866. ${ }^{9}$ This was the beginning of an extraordinary Wellington career. Between 1866 and his death in 1891, Toxward was responsible for the design of at least 240 buildings. From the start he ranged widely across styles, types of buildings and the lower North Island, working both on government contracts and in private practice. He worked as far north as Pātea and New Plymouth, as well as in the Wairarapa, besides an extremely prolific Wellington output. Everything was grist to his mill; churches, schools, warehouses, banks, dairy factories, ornate residences, simple shops, smelters, government offices; it seems there were no limits to his design capabilities.

Somehow, he also found time to be a

8 Archives New Zealand: WP 6, item 5, Outwards

Letters, Superintendent

9 "Tenders [Scotch Church]" p 8. company director for the Wellington Trust and Loan Company, a mine manager for the Wellington Quartz Crushing Company, and a Justice of the Peace. He was President of the first Association of Wellington Architects and Engineers, and was appointed Danish Consul in Wellington in June $1883 .{ }^{10}$ He had been a Grand Master of the Wellington Freemasons and remained a prominent participant throughout his life. ${ }^{11}$ At one stage, in May 1869 , it appeared he was diversifying away from architecture, setting up business with $C$ Hartmann as "Surveyors, Land, Estate and General Agents."12 This venture was however short-lived. He owned land in Palmerston North and near Pātea, almost certainly for speculative purposes. He became a naturalised New Zealand citizen in June 1867. Toxward died in 1891, aged just 59 while still controlling a thriving practice. Jane, his wife, had died from a bronchial infection in August that year, just over a month earlier.

William Charles Chatfield was born at

10 "The Wellington Association of Architects \& Civil Engineers [Advertisement]" p 3; "Several English journals record [untitled]" p 2.

11 "Freemasonry: Installation of Mr. Toxward as D.G.M. for the North Island" p 3.

12 "[Circular] [Advertisement]" p 3. 
Greatham Manor, Parham Park, Sussex, England in 1851. He was the son of Robert and Emma Maria Chatfield (née Derby). Both his mother and her relations were well-known artists who had exhibited at the London Academy of Fine Arts. His father was the local Squire Magistrate so it could well be said of Chatfield that he was born with a silver spoon in his mouth. After an education at Brixton in Surrey, Chatfield came to New Zealand on a trip for his health at the age of 16 for a visit, liked it and stayed on. It appears that he arrived on the Wild Duck in December 1867, although the Chatfield listed has no recorded forename. ${ }^{13}$ If his obituary is to be believed, he must have had some prior architectural training, as he is said to have set up a Wellington practice which ran from 1867 to 1872. At that point the obituary records that he joined the Public Works Department; specifically under the control of the Chief Engineer. Our research shows that he was actually employed by the Wellington Provincial Government, mainly as a draftsman in the District Engineer's office, for three years and seven months. From 1876 he went, or went back, into private practice as an architect with a home address in Upper Willis

13 "Arrival of the Wild Duck in Wellington" p :2.
Street. When he had married in October 1874 he was definitely a draftsman. His fiancé was Mary Hoggard, aged 21 and second daughter of the late Chief Postmaster of Wellington, John Hoggard. From 1876 onwards he made spectacular progress as an architect and was to become the first president of the newlyformed New Zealand Institute of Architects after its formation in $1905 .^{14}$

\section{Two Thorns and a Rose}

Tringham and Toxward between them account for 108 buildings, just under half of the architectural output we have found in Wellington from 1865-70. Despite research having uncovered references to nearly 20 different architects for this period, the majority only appear once or twice in tender notices. Some, such as Mr Moore above, were from other centres. Mason \& Clayton are another example, although Clayton moved to Wellington to become Colonial Architect in 1869; he was also allowed to practice privately, with the first of his private commissions appearing at the end of that year. Others, such as Richard Stelling Barker and George Greenfield either focused chiefly on other work with architecture as a sideline,

14 "Personal" Manawatu Standard (30 May 1930):6. or were builders masquerading as architects.

Both Tringham and Toxward started in Wellington in the mid-1860s with very pragmatic approaches and an eye for the main chance. Charles Tringham moved from builder to architect without formal training or going through an apprenticeship with an experienced architect. His drive and ability showed itself in the production at first of many houses and shops, soon diversifying into the design of a much greater range of building types of increased complexity and commanding higher architect's fees. He may have had access to the pattern books of the time and almost certainly subscribed to architectural journals in later years in order to produce intricate works like the Italianate tower that still graces the building housing Queen Margaret College in Hobson Street.

Toxward had the advantage of a secondary education but seems to have derived no ultimate qualification from it. Hence it appears that he also gained experience on the job. If he was indeed a draftsman before his arrival in New Zealand he would have been able to acquire architectural skills in the offices where he worked. Acting as Clerk of Works would also have given him first-hand 
experience of building techniques. His initial approaches to architectural work in Wellington were quite different from those of Tringham, but were equally single-minded. Clearly he started by making contact with people and organisations whom he thought might provide him with long-term employment. His first job was the Scotch Church followed by work for the Catholic Church on a renovation project (virtually a rebuild) in Hill Street. He also obtained work from the government designing schools and other buildings. His social contacts through freemasonry provided work and once his reputation was established there was a huge inflow of contracts.

Chatfield remains something of an enigma in the first years after his arrival in 1867. If he did indeed set up as an architect, it must have been relatively informally, as no tenders by him from the 1860s or early 1870s have been found. It is possible he obtained work through word of mouth and personal contacts; certainly some buildings were erected without tendering at that time. He may also have thought that family influence could be used to establish his position, but found this was not the case. Whatever the situation, his taking a job as draftsman with the Wellington
Provincial Government would seem to indicate a need for steady employment at least until better opportunities presented themselves. This work would also have enabled him to improve his skill base and make contact with others from whom he could later obtain contracts. Once established, his design skills, flair with building techniques and abilities to influence people were never in doubt.

\section{The Rest of the Pack}

Although Tringham and Toxward were way out in front in terms of design numbers in the mid to late 1860s and many of the other minor architects of the time had only one or two buildings to their names, two other men stand out mainly because of their later impact on the architectural scene. These were Nicholas Marchant and Benjamin Smith. The former was born in Devonshire, England, about 1836 and trained as a civil engineer. He migrated to New Zealand about 1864 under contract to Brogdens who were mainly engaged in railway building. His first recorded private architectural work in Wellington appears in December 1865 with a church at Karori, designed from an address in Cuba Street. By 1867 he was placing advertisements as an architect care of "Messrs. Kennard's Office" and had at least one further commission, to design the New Barrett's Hotel in September of that year in a "Venetia-Italian" style. In 1867 he was appointment Surveyor to the Wellington Board of Works. His work at that time included the supervision of road construction. In one instance in 1868 this proved unusually dangerous, as he was struck on the head and felled by a disgruntled worker on Adelaide Road who thought he was being paid for less than his fair share of the work. In 1870 with the formation of the Wellington City Council his title changed to City Surveyor and Waterworks Engineer, and from 1875 City Engineer. He retired from this position in March 1878 and returned to private practice, mainly as an architect, although he gave his profession as civil engineer on the 1881 Electoral Roll when he was living in Majoribanks Street. Between 1867 and 1884, he was involved in the design of at least 26 buildings and structures, covering a very wide range of types. These included nine houses, nine stores, a school, some club rooms, a hotel, a foundry, a kiln and associated structures, and two sets of waterworks, one at Marton in the Rangitikei region. By 1893 he was living at 2 Manners Street. In the latter part of the century he gradually retired and had been ailing for 
some time before his death in September 1907 aged 71 .

Benjamin Smith was born about 1827 at Tipton in Staffordshire, England. His parents were Ben and Ann Smith and his father was a mine manager. Nothing is known of Benjamin's education, but he married when he was 22. Four years later, in 1853. Because the name is a common one, it has not been established where they first settled, and it has proved difficult to trace all their movements. From 1861 there was a Benjamin Smith, architect and building surveyor, in Dunedin (who also ran the Octagon Timber Yard from around 1862) until at least late $1864 .{ }^{15}$ By October 1865 there was definitely a Ben Smith, architect, present in Wellington, as he designed a store on Lambton Quay for Jacob Joseph. ${ }^{16}$ A second identified tender was in the Evening Post in February 1866. ${ }^{17}$ However he had already been declared bankrupt at the end of October 1865 and was presumably

${ }^{15}$ In October 1864 Benjamin Smith, architect of Dunedin, was patenting "an improved method of Sluicing for Gold." See "A few weeks ago mention was made ... [untitled column 1]" p 5.

16 "The new store now in course of erection ... [untitled column 3]"p 2.

17 "To Builders" p 3. starting to try and trade his way out of it. We believe this is the same person although we have not found conclusive proof of his actual move from Dunedin. He was not listed in the New Zealand Directory for 1866, but in the 1867-68 volume he was described as architect and civil engineer with an office on Lambton Quay and a residence in Willis Street. He was involved in survey work for a railway route to the Wairarapa with Charles O'Neill in May 1868. Tenders have been found through to 1874, mainly giving his address as Willis Street. Subsequently he seems to have moved around the southern North Island designing in Whanganui, Napier and Waipukurau. It was while on his way to work near the latter township that he was killed by a train in March 1883.

\section{Conclusions}

The Wellington of the early 1860s was in essence a small town with a large workforce of carpenters and small-scale builders, but very few professional architects. The transfer of capital status from Auckland marked a major turning point, with the relocation of business head offices and the growth of government departments. These trends provided opportunities for both established and aspiring architects who migrated to the new capital and competed for the new work well into the 1870 s.

We have identified and described the two most active architects from the mid-1860s, Tringham and Toxward, and have demonstrated some of the sharp characteristics that ensured their success. Both were hardworking and outgoing and rapidly established reputations for reliability. Chatfield was to do the same somewhat later in time and had a less stormy professional career than his rival, Thomas Turnbull.

Marchant and Smith are briefly noted as examples of architects who worked in Wellington in the 1860s, but gained far less work than the main players and who either changed jobs or sought additional work in other parts of the country. Although both were capable and entrepreneurial, they seem not to have had the ability to compete effectively with the leading players. 


\section{REFERENCES}

Extensive use has been made of early newspapers, in particular the Evening Post, Otago Daily Times, Otago Witness and Wellington Independent. A full list is not included here, but specific issues are referenced in the text where relevant.

"Arrival of the Wild Duck in Wellington" Wanganui Herald (24 December 1867):2.

Benjamin Smith Bankruptcy Files, Trustee's Report, 15 June 1870. AAOM, W3843, B1870/109, Archives New Zealand, Wellington

Brodie, James Terawhiti and the Goldfields Wellington: Karori Historical Society, 1986.

Burr, Valerie A Mosquitos E Sawdust, A history of the Scandinavians in NZ Scandinavian Club of Manawatu, 1995.

"[Circular] [Advertisement]" Evening Post (22 May 1869):3.

Cochran, Chris Christian Julius Toxward in: The Dictionary of New Zealand Biography. Volume 2, 1870-1900 Bridget Williams Books \& Department of Internal Affairs, 1993.

"Death of an Early Southlander" Southland Times (2 October 1891):2.

"District Court: This Day" Evening Post (18 January 1867):2.

Fearnley, Charles Early Wellington Churches Wellington: Millwood Press, 1977.

"A few weeks ago mention was made ... [untitled column 1]" Otago Daily Times (31 October 1864):5.

"Freemasonry: Installation of Mr. Toxward as D.G.M. for the North Island" New Zealand Times (26 August 1879):3.

Furkert, F.W. Early New Zealand Engineers Wellington: A.H. \& A.W. Reed, 1953.

Ilott, J.M.A. A Chronicle of the Foundation and Progress of the Wellington Lodge 1521 EC: of the most ancient and honourable fraternity of free and accepted masons under the United Grand Lodge of England. Wellington: Harry H. Tombs Ltd, 1925.
"Local and General News: The Bank of Australasia" Wellington Independent (19 May 1866):4.

"Local and General News: Bank of Australasia" Wellington Independent (23 August 1866):4.

"Local Intelligence: Architecture" Wellington Independent (30 September 1862):2.

Macgregor, Miriam Florence Early Stations of Hawke's Bay Wellington: A.H. and A.W. Reed, 1970.

McKeon, W.J. "Architects I Have Known" Journal of the New Zealand Institute of Architects (9 October 1962) 29:267-275

"The new store now in course of erection ... [untitled column 3]" Evening Post (5 October 1865):2.

"Personal" Manawatu Standard (30 May 1930):6.

Probate Number 46685 - William Charles Chatfield, 1930, AAOM. Series 6029, Archives New Zealand, Wellington

"Several English journals record [untitled]" Evening Post (30 May 1883):2.

"Tenders [Scotch Church]" Wellington Independent (3 March 1866):8.

"To Builders" Evening Post (27 February 1866):3.

"We find the following, in the Wellington letter ... [untitled column 4]" Daily Southern Cross (5 June 1866):3.

"The Wellington Association of Architects \& Civil Engineers [Advertisement]" Evening Post (20 August 1883):3. 